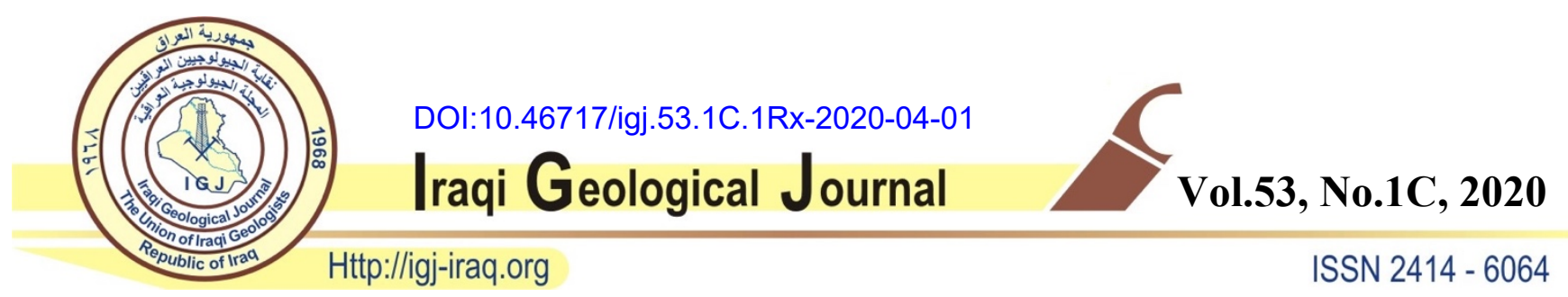

\title{
DEDUCING THE LATERAL GROWTH OF HANDREEN, ZOZIK AND TANOUN ANTICLINES IN KURDISTAN REGION USING GEOMORPHOLOGICAL FEATURES
}

\author{
${ }^{1}$ Varoujan K. Sissakian ${ }^{2}{ }^{1}$ Hawkar A. Abdulhaq, ${ }^{1}$ Ala A. Ghafur and ${ }^{1}$ Hassan O. Omer \\ ${ }^{1}$ University of Kurdistan Hewler, KRG, Iraq \\ *E-mail: f.khajeek@ukh.edu.krd
}

Received: 3 December 2019; accepted: 6 February 2020

\begin{abstract}
Handreen, Zozik and Tanoun are three major anticlines in the northern part of Iraqi Kurdistan Region located $N E$ of Rawandouz town. All anticlines are oriented $N W-S E$ with a steep southwestern limb. The length and width of Handreen, Zozik and Tanoun anticlines are 20.2 $\mathrm{km}, 23 \mathrm{~km}, 27 \mathrm{~km}$, and $10 \mathrm{~km}, 4.7 \mathrm{~km}$ and $2.5 \mathrm{~km}$, respectively. The anticlines are separated by very narrow synclines. However, Tanoun anticline is thrusted over Zozik anticline causing the disappearance of the synclinal axis between the two folds. The oldest exposed rocks in Handreen anticline are the Cretaceous age, in Zozik anticline are the Upper Jurassic rocks, whereas in Tanoun anticline, the Lower Jurassic rocks are exposed. The carapace of Handreen and Zozik anticlines is built up by Bekhme and Qamchuqa formations and that of Tanoun anticline by the Qamchuqa Formation. Satellite images and geological maps were used to recognize the geomorphological and structural features which were checked and confirmed in the field. It was found that Handreen, Zozik and Tanoun anticlines show clear geomorphological and structural features which indicate their lateral growth. Among those features are water gaps, wind gaps, forked-shaped valleys, curved valleys, inclined (curved) valleys, radial valleys, abandoned alluvial fans, wale-back shape, en-echelon folds and folds with malty domes.

Keywords: Lateral growth; Water and wind gaps; Fork-shaped valleys; Radial valleys; Curved valleys
\end{abstract}

\section{INTRODUCTION}

The lateral growth of anticlines is a very common phenomenon in tectonically active areas (e.g. Blanc et al., 2003, Bennett et al., 2005, Ramsey et al., 2008) such as the Iraqi Kurdistan territory, which forms the northeastern part of the Arabian Plate. The Arabian Plate is in collision with the 
Eurasian (Iranian) Plate with convergent tectonic plate boundary (e.g. Alavi, 2004, Allen et al., 2004 and Fouad, 2012) and the existing anticlines in the region and associated main thrust faults within the anticlines are developed due to the exerted stress forces by the collision. Moreover, mountain building and landscape evolution are controlled by interactions between river dynamics and tectonic forces (Colligon, et al., 2016). Landscape geomorphology and drainage patterns as well provide indirect information on tectonic activity (e.g. Oberlander, 1985; Alvarez, 1999; Bretis et al., 2011; Burbank and Pinter, 1996; Burbank and Anderson, 2001; Keller et al., 1999; Tomkin and Braun, 1999; Castltart and Simson, 2006; -Graseman and Schmalholz, 2012; Colligon, et al., 2016). Keller et al. (1999) described geomorphic criteria to evaluate fold growth: the deformation of progressively younger deposits or landforms; the development of characteristic asymmetric drainage patterns; the occurrence of a series of wind gaps with decreasing elevation in the propagation direction.

Handreen, Zozik and Tanoun anticlines exhibit lateral growth with clear indications of interaction between the existing rivers and streams, and tectonic forces; as indicted by different geomorphological features, which are emphasized in the current study. Some research works were carried out in Iraqi Kurdustan Region which deal with the lateral growth of folds and other tectonogeomorphological studies among them are: Sissakian (2010) conducted a tectonicgeomorphological study on Derbendi Bazian gorge, which represents a wind gap and attributed the development of the gorge to neotectonic activity. Sissakian and Abdul Jab'bar (2010) conducted a study about the transversal gorges, among them are Basara gorge which represents a water gap and concluded that the gorge is developed due to neotectonic activity. Sissakian and Fouad (2014) updated the geological map of Erbil and Mahabad Quadrangles at a scale of 1:250000. Handreen, Zozik and Tanoun anticlines are located within the updated map, they demonstrated the details of the structural features. Sissakian et al. (2014) conducted a geomorphological study of the High Folded Zone and attributed the developed gorges in Handreen, Zozik and Tanoun anticlines to the lateral propagation (growth) of the anticlines. Al-Kubaisi and Abdul Jab'bar (2015) conducted a morphotectonic study for two folds (Pera Magroon and Qara Dagh anticlines) in the Kurdistan Region and their effect on the drainage systems. They indicated high tectonic activity and low maturity of the drainage basins in the studied anticlines. Sissakian et al. (2018) conducted a tectonogeomorphological study on Qara Dagh anticline to indicate its lateral growth by means of the same geomorphological forms which are used in the current study. Ghafur et al. (2019) conducted a tectonic- geomorphologic study on Aqra anticline confirming its lateral growth using 
geomorphological and structural forms. Many international studies deal with the subject of the current study, some of them are shown below: Cartwright et al. (1995) conducted a geomorphological study to deduce the fault growth by segment linkage from the Canyon lands Grabens of SE Utah, USA. Bennett et al. (2005) conducted geomorphological study in South Rough Ridge, Central Otago, New Zealand to deduce the lateral growth of a ridge along a blind fault. They used geomorphological data to confirm the lateral growth; some of those geomorphological forms were used in the current study. Mumipour and Najad (2011), and Mousavi and Arian (2015) conducted tectonic- geomorphological studies in Zagros Belt; Iran using geomorphological features to deduce the growth of anticlines. Whitney and Hengesh (2015) used geomorphological evidences to recognize Neotectonic deformation in Carnavaran Basin in Western Australia. The same evidences were recognized in the study area.

The studied area includes Handreen, Zozik and Tanoun anticlines, which are located about $80 \mathrm{~km}$ northeast of Erbil city and few kilometers north of Rwandouz town within the Iraqi Kurdistan Region (Fig. 1). Handreen and Zozik anticlines are outstanding mountains in the region.

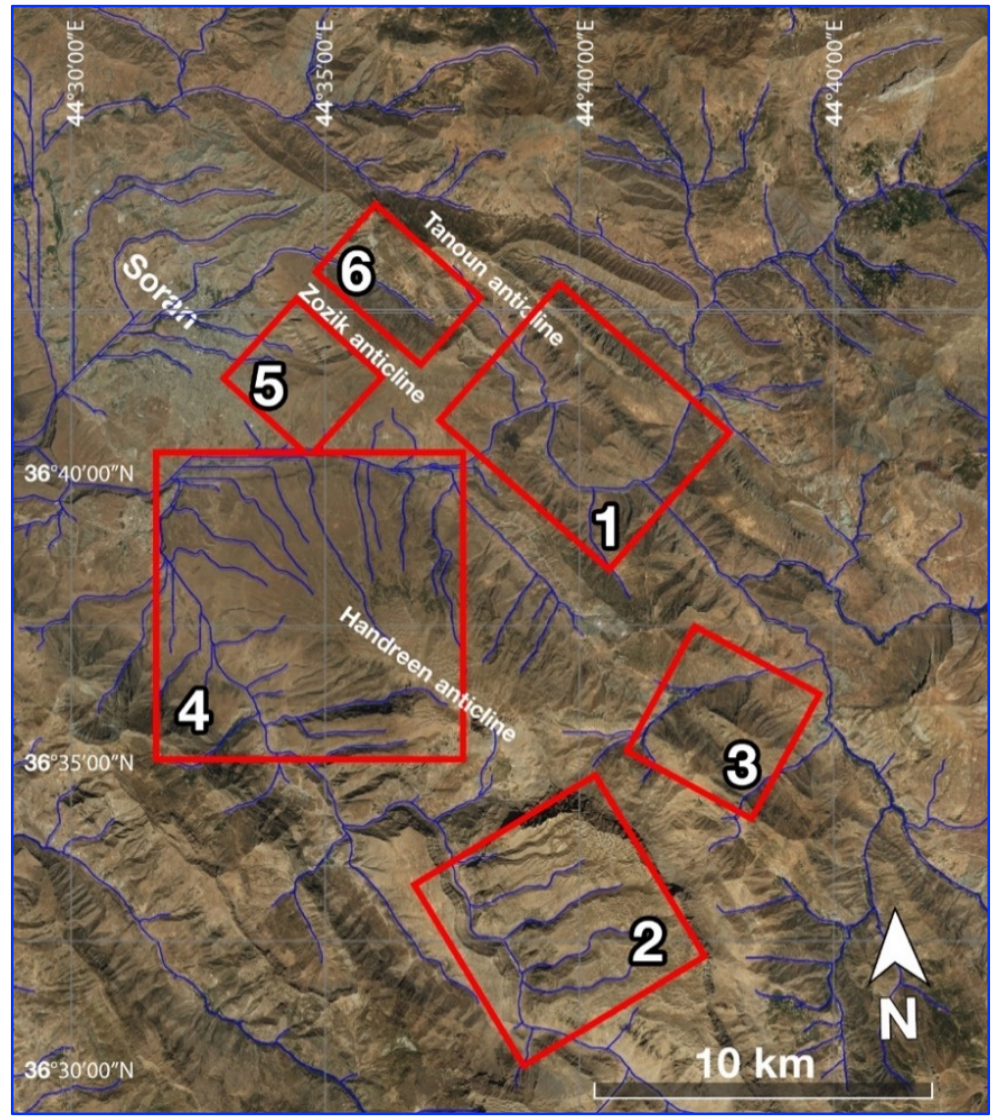

Fig. 1. Satellite image of the study area showing Handreen, Zozik and Tanoun mountains with the locations of the sited Figures $(1-6)$ in the text 
The aim of the current study is to confirm the lateral growth of Handreen, Zozik and Tanoun anticlines using geomorphological and structural features, which are developed in the studied anticlines. The recognition of the features took place by interpretation of high-resolution satellite images and field checking.

\section{MATERIALS AND METHODS}

In order to perform the current work and fulfill its aim, the following materials were used:

- Geological maps at a scale of 1: 100000 and 1:250000.

- Topographical maps at a scale of 1: 100000.

- Satellite images of high resolution.

- Filed work was conducted to check and confirm the recognized geomorphological features and collect geomorphological and structural data. Heights of terrace levels, depth of streams, abandoned and dislocated alluvial fans, indication for wind and water gaps were also checked and recorded in the field.

The opinions of different researchers have been considered in recognition of geomorphological features which indicate the lateral growth of anticlines in the study area, and the achieved conclusions from the current work. Among the researchers are Killer et al. (1999); Ramsey et al. (2008); Grasemann and Schmalholz (2012) and Collignon et al. (2016). Using the available topographical and geological maps of 1: 100000 and 1: 250000 scales with the help of FLASH Earth, Global Mapper, DEM images, different geomorphological features were interpreted to indicate the lateral growth of Handreen Zozik and Tanoun anticlines. Different geomorphological studies in Zagros Range were reviewed to deduce the indication for the growth of the studied anticlines, their evolution and their current shapes.

\section{Geomorphological Features Used in the Current Study}

Geomorphological features which can be used as markers such as wind gaps and river (water) gaps (or transverse streams) have been extensively used to define the style of deformation and to quantify both the rate and the direction of propagation (or the lateral growth) of fault and fold segments (Burbank and Pinter, 1999; Delcailleau et al., 2006; Keller et al., 1999; Ramsey et al., 2008 and Bretis et al., 2011;). Water gaps represent valleys that are developed by carving the exposed rocks during fold growth and that still host a flowing stream, whereas wind gaps constitute similar valleys that are presently dry; witnessing the previous water gap. The development of water gaps, wind gaps and radial valleys is illustrated in Fig. 2. 
The rate of rock and surface uplift, which shape landscapes are controlled by deformation stresses, climate and rock properties. Understanding the interaction between these parameters and how they determine the formation of wind gaps is a question with direct implications for predicting the release of sediments in local basins and at the outlet of fluvial basins (Gupta, 1997; Collignon et al., 2016). To understand the development of water gaps and their changes (locally) to wind gaps, and the radial valleys (Fig. 3.1, 3.3 and 3.4), the opinion of Ramsey et al. (2008) is adopted. Furthermore, abandoned alluvial fans (Fig. 3.5) can be considered as an important indicator for active tectonics without ignoring the role of climate change in the existence of abandoned alluvial fans.

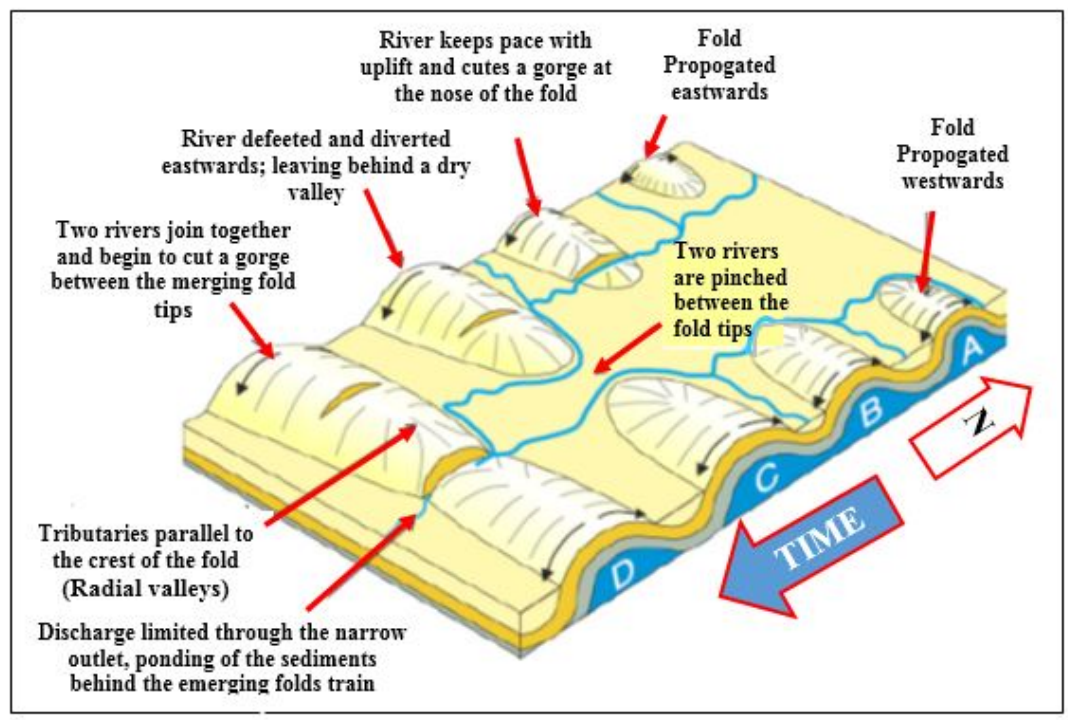

Fig. 2. Diagrammatic show of the formation of a gorge between two propagating anticlines through time. (A) Two small folds' form in the east and west of the landscape. (B) The folds propagate towards one another. Growth on aligned fold segments is enhanced by positive feedback in the stress changes around each growing fold. The incision rate of the western river keeps pace with uplift and the river incises a gorge through the nose of the fold. (C) The western river is unable to keep pace with uplift and the gorge is abandoned and left as a dry valley (Wind gap). The river is diverted to the east and pinched between the tips of the two folds. (D) The folds continue to propagate towards one another and the tips of the folds begin to form a continuous structure. The rivers have increased their stream power by joining together and incise a gorge through the almost continuous anticline (Water gap) (Ramsey et al., 2008) 


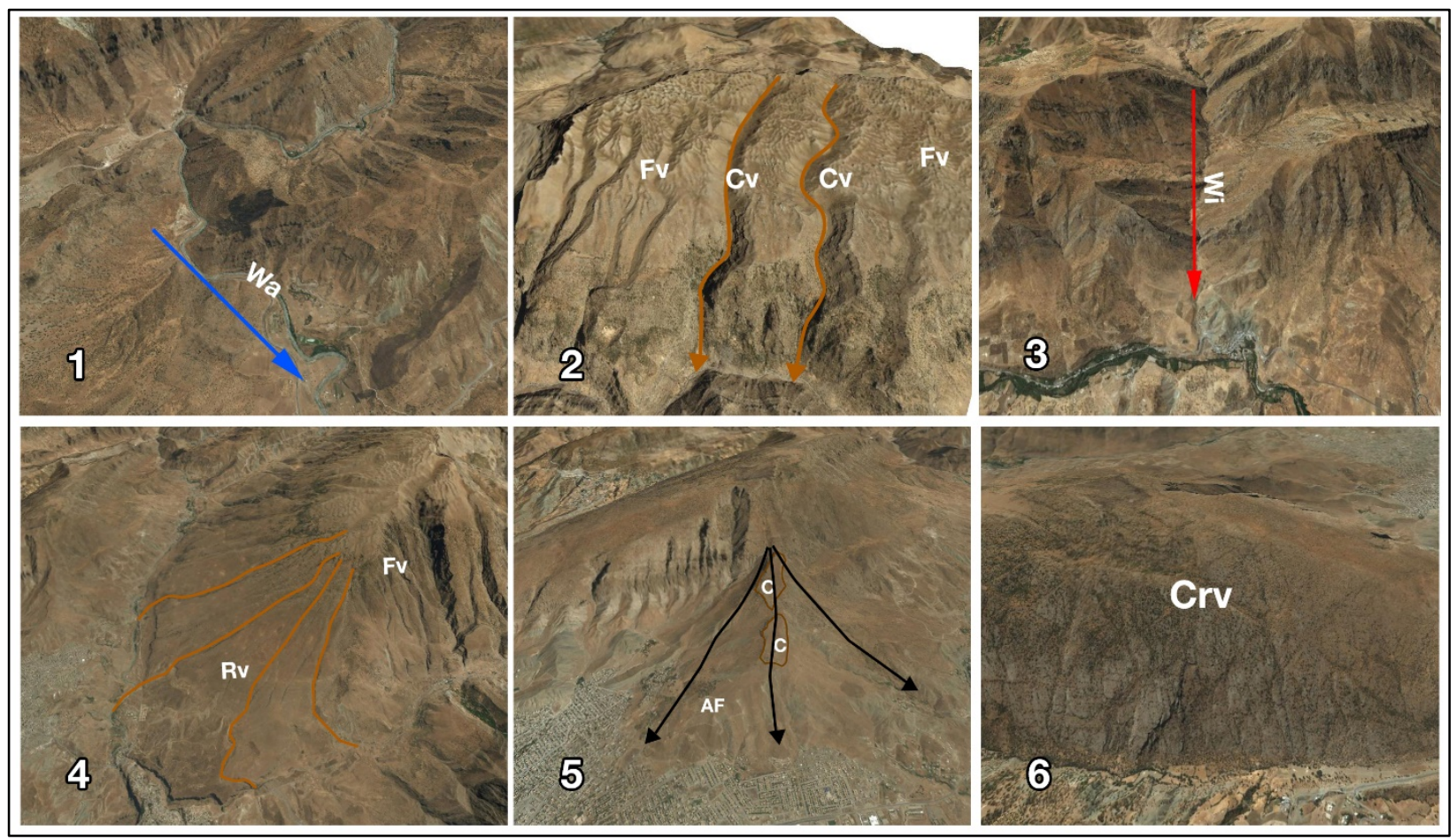

Fig. 3. Satellite images of different geomorphological forms used in the current study:

(1) Water gap (Wa), (2) Curved valleys (Cv); on both sides fine Fork-shaped valleys (Fv)

(2) Wind gap (Wi), (4) Radial valleys (Rv), Fork-shaped valleys (Fv) on the upper right

(3) corner, (5) Abandoned alluvial fan (AF), on the top there are relics of calcrete (C), and

(6) Cross-shaped valleys (Crv) (For location; refer to Fig. 1

Also, Skilodimou (2014) revealed the importance of lateral growth and uplifts of folds as indications of active tectonics. Axial valleys on top of elevated areas are a good indication for active tectonics (Cannat et al., 1999). Zozik and Tanoun anticlines show axial valleys. Field investigations were carried out in Handreen, Zozik and Tanoun anticlines in order to check some vague interpreted geomorphological features, and to perform some measurements which were used in the current study. Moreover, some geomorphological features like abandoned alluvial fans, deviation of feeder channels, degraded flood plains, terraces were recognized and used as indications for the lateral growth.

\section{GEOLOGICAL SETTING}

The geological setting of the studied area is briefed hereinafter; including geomorphology, tectonics and structural geology and stratigraphy. The presented data is based on Sissakian and Fouad, 2012 and 2014; Sissakian and Al-Jibouri, 2014 and Sissakian et al., 2014). Geomorphologically, the studied area is mountainous with very rugged cliffs and steep slopes 
dissected by deep gorges. The highest peaks in Handreen, Zozik and Tanoun mountains are 2562 $\mathrm{m}, 1833 \mathrm{~m}$ and $1882 \mathrm{~m}$, respectively. The main geomorphological forms are: Anticlinal ridges, structurally controlled cliffs, abandoned alluvial fans, water and wind gaps, extensive karstification, dissected slopes and landslides.

Tectonically, the studied area is located in the High Folded and Imbricate Zones represented by Handreen, Zozik and Tanoun anticlines, respectively. Both zones belong to the Outer Platform of the Arabian Plate (Fouad, 2012), and are part of the Zagros Fold - Thrust Belt (e.g. Alavi, 2004; Berberian, Ramsey et al., 2008). Handreen anticline is a double plunging anticline trending NW SE, consists of two parts, they are called in the current study as Handreen East and Handreen West anticlines; the former has three domes (H1, H2 and H3) (Fig. 4). The north western plunge of Handreen west anticline is very steep with radial valleys, whereas its south eastern plunge and both plunges of Handreen East anticline are truncated by an erosional scarp (Figs. 1 and 4). A normal fault (about $5 \mathrm{~km}$ in length) along the north eastern limb (Fig. 4) has truncated Bekhme and Shiranish formations.

Both Zozik and Tanoun anticlines are double plunging anticlines trending NW - SE. Both anticlines are dissected by thrust faults which run in the same anticlinal trend. In Zozik anticline, large parts of the axis (the central part) has covered by the thrusted block, whereas in Tanoun anticline, large parts of the south western limb are truncated by the thrust fault (Fig. 4). In Zozik and Tanoun anticlines, the disappearance of the south western limbs has left the soft rocks in the core of both anticlines to be extensively eroded and accordingly many wind gaps and water gaps were developed (Figs. 1 and 3). Zozik anticline includes five domes (Z1 - Z5); whereas Tanoun anticline includes three domes (T1, T2 and T3) (Fig. 4).

The exposed formations in the studied area are briefly described hereinafter, from the older to the younger. Only those formations which are exposed in Handreen, Zozik and Tanoun anticlines (Fig. 4) are briefed.

1- Sarki Formation (Lower Jurassic): The formation consists of massive dolostone and limestone, very hard, white and grey in color. The thickness of the formation, when the lower contact is exposed, is about $300 \mathrm{~m}$, otherwise it ranges from $(100-250) \mathrm{m}$.

2- Sehkaniyan Formation (Lower Jurassic): The formation consists mainly of dolomite and limestone dark in color, hard, thickly well bedded and massive. The thickness of the formation ranges from $(200-250) \mathrm{m}$, decreasing northwestwards. 
3- Sargelu Formation (Middle Jurassic): The Sargelu Formation consists of black, thinly bedded clayey limestone and shales with black chert and brown dolomitic limestone, usually very fossiliferous. The thickness of the formation ranges between $(100-125) \mathrm{m}$.

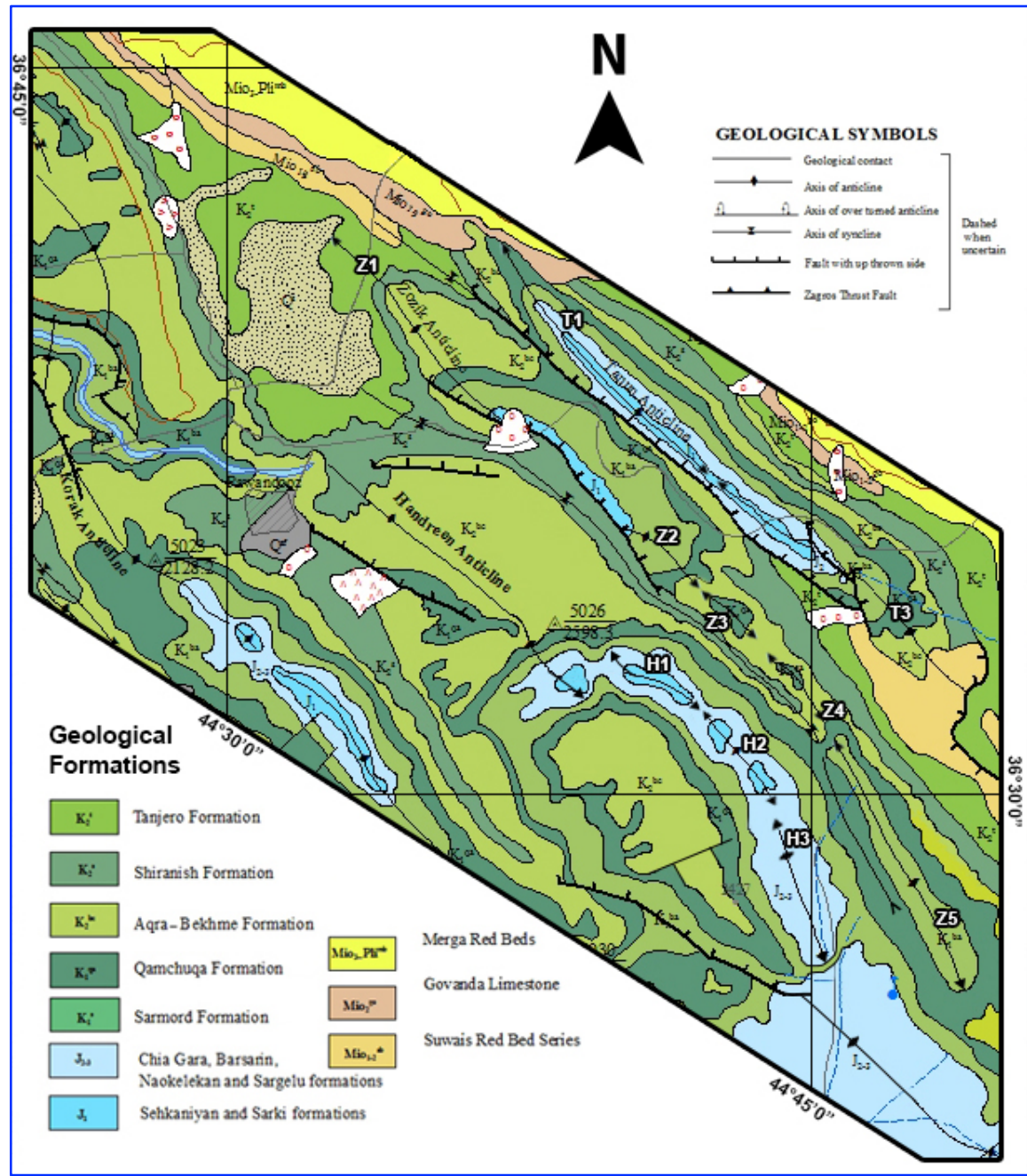

Fig. 4. Geological map of the studied area (modified from Sissakian and Fouad, 2014), The serial numbers $(\mathrm{H1}-\mathrm{H3}, \mathrm{Z1}-\mathrm{Z5}$ and $\mathrm{T} 1-\mathrm{T} 3$ are the serial numbers of the recognized domes

4- Naokelekan Formation (Upper Jurassic): The formation consists of laminated shaley limestone, hard dark grey limestone, thinly bedded bituminous limestone and calcareous shale "coal horizon". The thickness of the formation in the type locality is $14 \mathrm{~m}$, which is $30 \mathrm{~km}$ eastwards from the study area.

5- Barsarin Formation (Upper Jurassic): The formation consists of laminated limestone and dolomitic limestone, some fluffy textured, locally chert, alternately in normal beds and in 
brecciated, crumbed and contorted beds. The thickness of the formation in the type locality, which is just south of the studied area is $17 \mathrm{~m}$.

6- Chia Gara Formation (Upper Jurassic - Lower Cretaceous): The formation consists of thinly bedded limestone and shales, rich in ammonite fauna; grading upwards into yellowish marly limestone and shale. The thickness of the formation is about $30 \mathrm{~m}$.

7- Sarmord Formation (Lower Cretaceous): The formation consists of thinly bedded limestone, dolomitic limestone interbedded with soft marl beds, usually dark grey and light brown in color. The thickness of the formation in Rawandouz is $500 \mathrm{~m}$.

8- Qamchuqa Formation (Lower Cretaceous): The formation consists of massive limestone, dolomitic limestone and dolomite, usually dark grey and light brown in color. The thickness of the formation in Rawandouz is $1000 \mathrm{~m}$.

9- Bekhme Formation (Upper Cretaceous): The formation consists of well bedded limestone and dolostone, locally bituminous, coralline and recrystallized with rudist, very hard, light grey in color. The thickness of the formation in Rawandouz is $75 \mathrm{~m}$.

10-Shiranish Formation (Upper Cretaceous): The formation consists of thinly well bedded marly and chalky limestone, white, yellowish white and greyish white in color, followed (upwards) by thinly bedded or papery marl, blue and grey in color with some marly limestone beds too. The thickness of the formation is $300 \mathrm{~m}$.

11- Tanjero Formation (Upper Cretaceous): The formation consists of an alternation of dark green and yellowish green shale, claystone, sandstone and siltstone; some conglomerate beds occur in the upper part and some marly limestone in the lower part. The thickness of the formation in Rawandouz is $2000 \mathrm{~m}$.

12-River Terraces (Pleistocene): Three stages of river terraces are recognized along the Rawanduz River and its main branches. However, the first (oldest) stage is not well preserved as the other two stages.

\section{RESULTS}

Different drainage shapes and types which exist in all anticlines (Table 1) and confirm the lateral growth of the studied anticlines were recognized during the interpretation of the images and locally geological and topographic maps. The interpreted forms are also used by different authors to confirm the lateral growth of anticlines, among them are: Keller et al. (1999); Keller and Pinter (2002); Ramsey et al. (2008); Grasemann and Schmalholz (2012) and Collignon et al. (2016). The recognized and described geomorphological features were also described by Burbank and 
Anderson (2001), they reported that the networks of mountain belts are perhaps the most sensitive indicators of horizontal and vertical surface deformation, at least on Holocene time scales. Grasemann and Schmalholz (2012) mentioned that the lateral growth of some anticlines may lead the development of one long anticline without visible interaction.

Table 1. The recognized geomorphological features in the studied anticlines

\begin{tabular}{|c|c|c|c|c|c|c|c|c|c|}
\hline \multirow{3}{*}{$\frac{.}{. e}$} & \multicolumn{9}{|c|}{ Geomorphological Features } \\
\hline & \multirow[b]{2}{*}{$\begin{array}{c}\text { Water } \\
\text { Gap }\end{array}$} & \multirow[b]{2}{*}{$\begin{array}{l}\text { Wind } \\
\text { Gap }\end{array}$} & \multirow[b]{2}{*}{$\begin{array}{l}\text { Abandoned } \\
\text { alluvial } \\
\text { fans }\end{array}$} & \multirow[b]{2}{*}{$\begin{array}{c}\text { Whale- } \\
\text { Shape } \\
\text { anticline }\end{array}$} & \multicolumn{5}{|c|}{ Valleys } \\
\hline & & & & & $\overbrace{}^{0}$ & 突 & $\stackrel{\bar{\pi}}{\frac{\pi}{4}}$ & 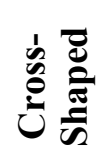 & 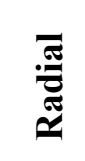 \\
\hline Handreen & No & Yes & Yes & Yes & Yes & Yes & Yes & Yes & Yes \\
\hline Zozik & Yes & Yes & Yes & No & Yes & Yes & Yes & Yes & No \\
\hline Tanoun & Yes & No & Yes & No & Yes & Yes & Yes & Yes & Yes \\
\hline
\end{tabular}

Water Gaps: Zozik and Tanoun anticlines show many water gaps (Fig. 5) indicating lateral growth. The former has two water gaps. One is located before the northwestern plunge of the anticline near Zewa village. The second one is located south east of the southeastern plunge and south of the two wind gaps. The latter has also two water gaps; the first one is located almost in middle of the anticline, whereas the second one is of complex type. The water gap is divided into two parts connected by an axial valley; the western part flows out of the anticline near Razanuk village; it is engulfed by Rawandouz River (Fig. 5). Handreen anticline does not show water gap. Wind Gaps: Zozik anticline shows two wind gaps which are successive to each other with a separation distance between them of $1.2 \mathrm{~km}$. Both are located near the south eastern plunge area (Fig. 5). Wind gaps indicate lateral growth. Handreen anticline shows one wind gap located at the top of the anticline, whereas Tanoun anticline does not include wind gap (Figs. 5 and 6). 


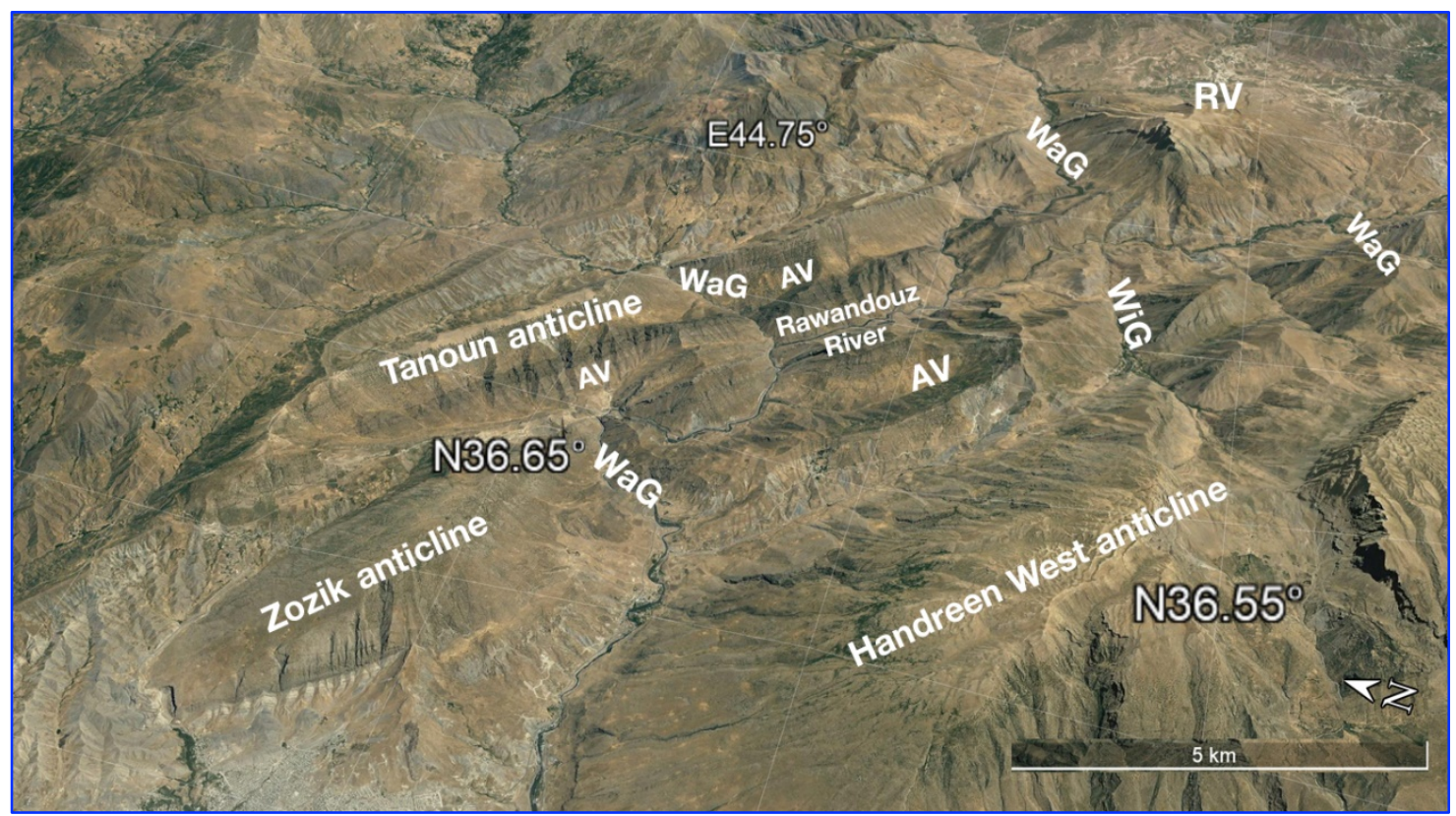

Fig. 5. Satellite image of Zozik and Tanoun anticlines showing water gaps (WaG) and wind gaps (WiG) and many geomorphological forms indicating lateral growth of both anticlines. Valleys: $\mathbf{A V}=$ Axial, $\mathrm{RV}=$ Radial

Curved (inclined), Fork-shaped, Axial, Cross-shaped and Radial Valleys: The presence of these valleys indicate Neotectonic activities and lateral growth of the anticlines as it is presented previously. All the studied anticlines show tens of such examples in different parts; some of them are presented in Figs. (6 and 7). Radial valleys are developed only in the plunge areas, especially in the northwestern plunge of Handreen anticline. Cross-shaped valleys are developed along bedding planes which exhibit two joint sets which are perpendicular to each other.

Abandoned Alluvial Fans: The presence of abandoned alluvial fans is good indication for Neotectonic activity and lateral growth of folds (Ramsey et al., 2008). In all studied anticlines abandoned alluvial fans were recognized (Fig. 7), with different sizes and shapes depending on the size of the valley, type of the exposed rocks and gradient change. However, alluvial fans can be abandoned due to climatic changes. 


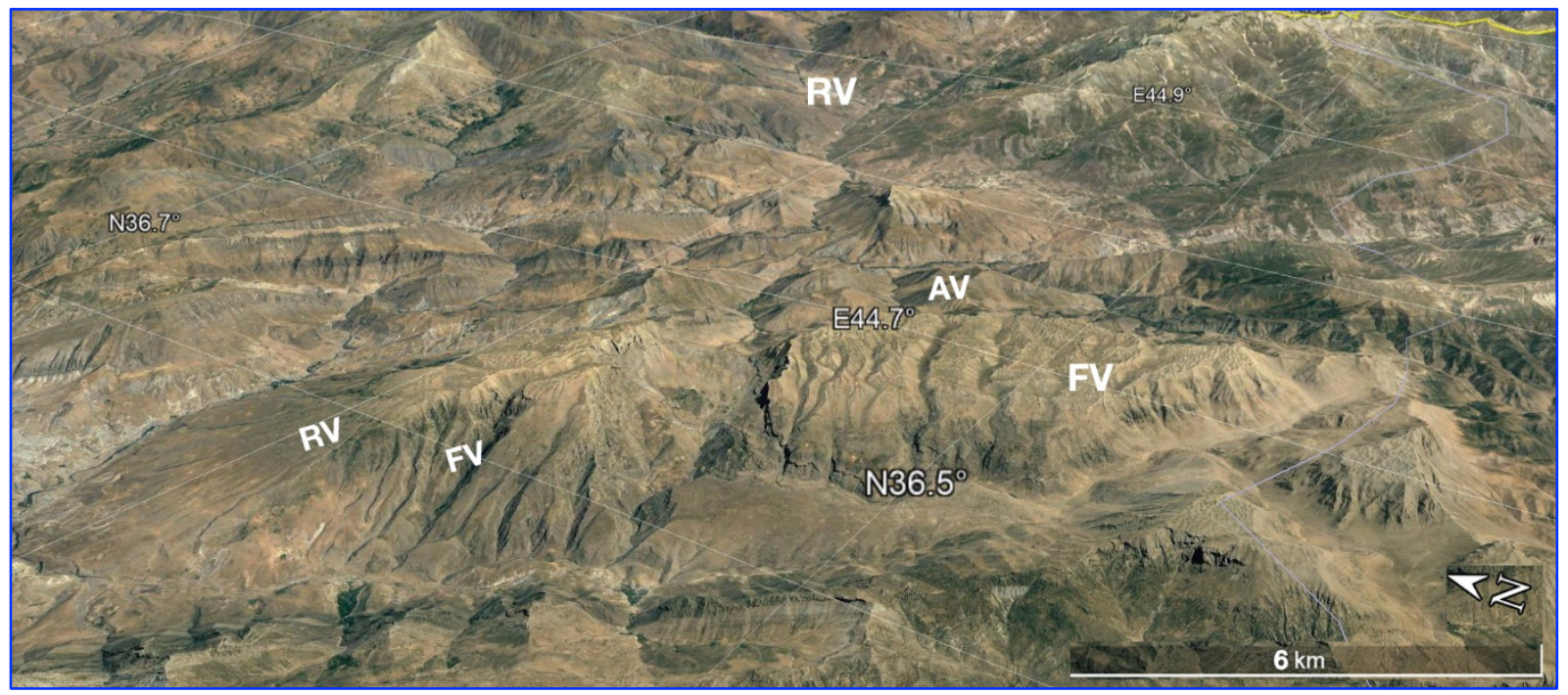

Fig. 6. Satellite image of Handreen anticline showing geomorphological forms which indicate Neotectonic activities. Valleys: $R V=$ Radial, $A V=$ Axial, and FV= Fork-shaped

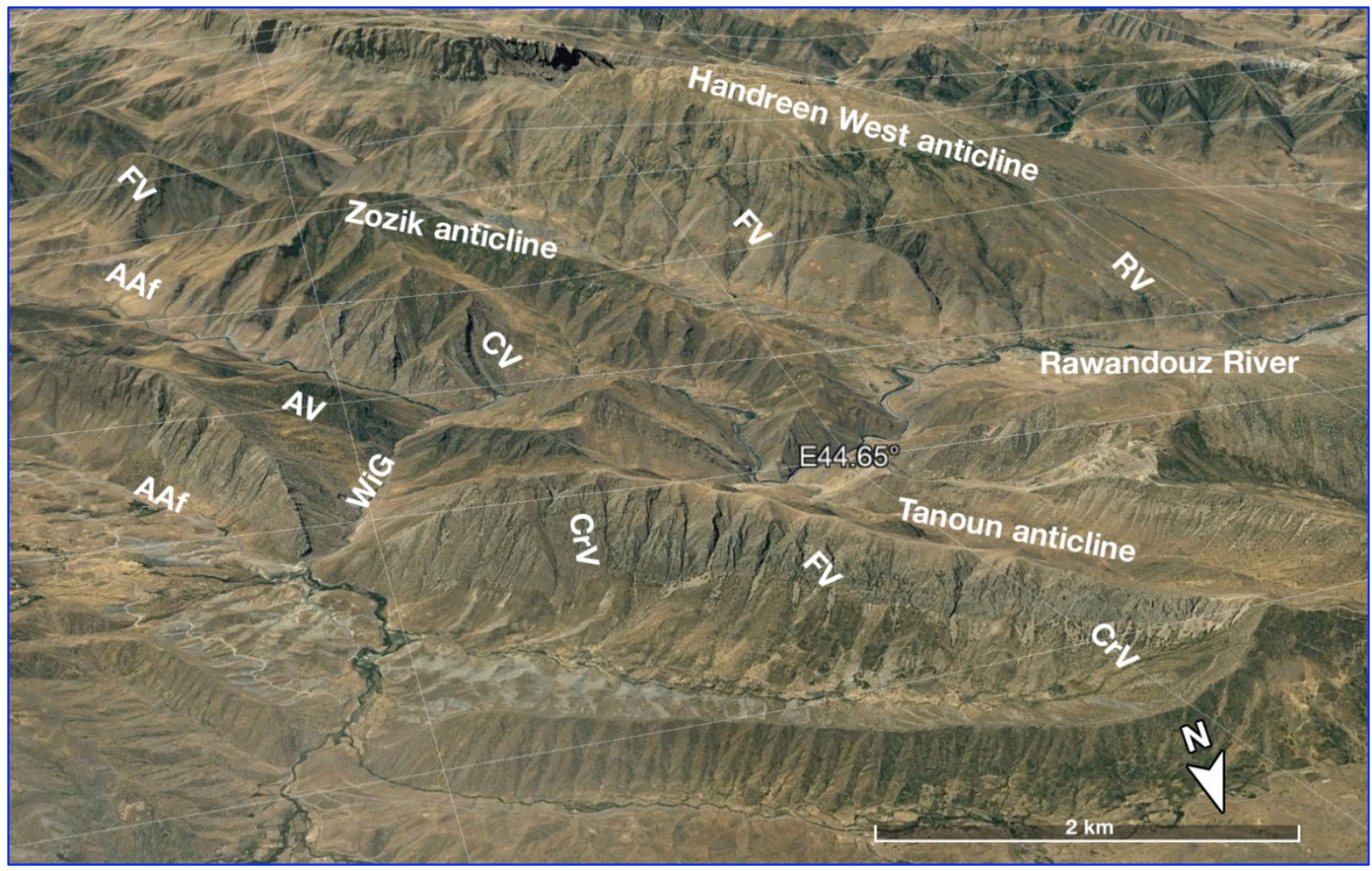

Fig. 7. Satellite image of Zozik and Tanoun anticlines and part of Handreen anticline showing geomorphological forms. Valleys: $\mathrm{RV}=$ Radial, $\mathrm{AV}=\mathrm{Axial}, \mathrm{CV}=\mathrm{Curved}, \mathrm{CrV}=$ Cross-shaped, $F V=$ Fork-shaped. $\mathrm{WiG}=$ Wind gap, and $\mathrm{AAf}=\mathbf{A b a n d o n e d}$ alluvial fan 
En echelon Folds and Malty Dome Folds: Folds with en-echelon plunges are a good indication for lateral growth (Killer and Pinter, 2002 and Ramsey et al., 2008). Folds with different domes are also an indication for the lateral growth of folds (Cartwright et al., 1995; Dawers and Anders, 1995; Cowie, 1998; Blanc et al., 2003 and Bennett et al., 2005). Moreover, Grasemann and Schmalholz (2012) mentioned that growing folds can join each other forming one single fold. In Handreen, Zozik and Tanoun anticlines, there are many en-echelon plunges and all of them show domes (Fig. 8). Domes of Handreen anticline are called H1, H2 and H3, those of Zozik anticline are Z1, Z2, Z3, Z4 and Z5, and those of Tanoun anticline are T1, T2 and T3 (Fig. 8).

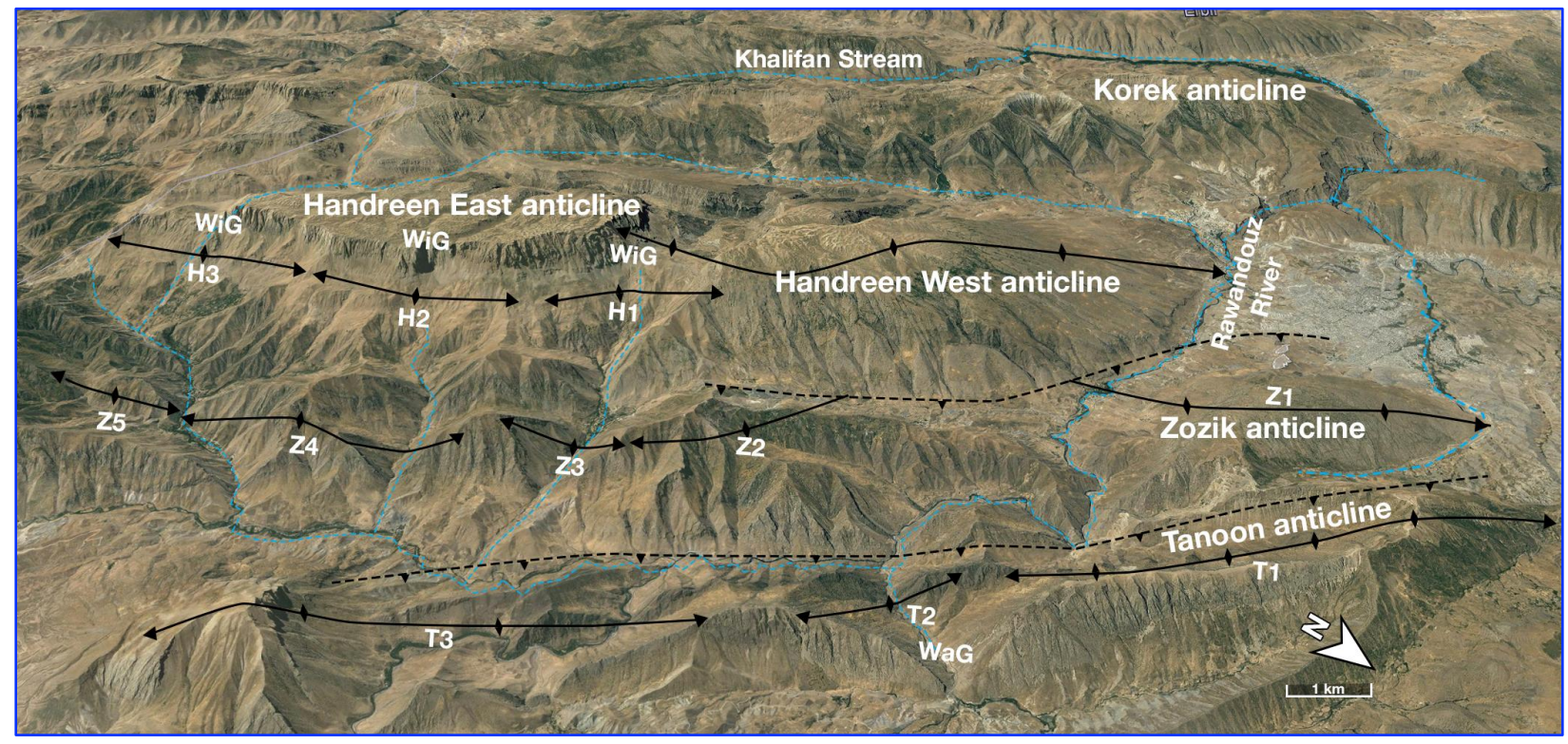

Fig. 8. Satellite image showing en-echelon plunges, doming folds, water gaps (WaG) and wind gaps (WiG). Thrust faults (dashed black lines). Dome numbers (on the axes of anticlines). Solid blue line is the Rawandouz river and its tributaries, dashed blue lines are wind gaps and some selected valleys

Incision of Streams and Terraces: Stream incisions and terrace levels and their heights are good indications for the tectonic activity of any concerned area. Following the opinion of Ramsey et al. (2008), the terrace levels were checked in the studied area and compared with the water gaps and wind gaps. The main stream in the studied area is Rawandouz River with many small tributaries. Along the river and the tributaries, two level of terraces were recognized although a third level was recognized only in one location, they are the usual levels of terraces in Kurdistan Region (Hamza, 1998). The third (younger) level is about $(6-8) \mathrm{m}$ above the present river and/ or stream level with thickness of $(4-6) \mathrm{m}$. The second (Middle) level is $(18-20) \mathrm{m}$ above the present river and/ or 
stream level with thickness of $(3-4) \mathrm{m}$ (Fig. 9). The First level (Oldest) is recognized only at the plunge area of Zozik anticline. This level is $(75-80) \mathrm{m}$ (Fig. 9 Bottom Right) above the present river and/ or stream level with thickness of $(30-35) \mathrm{m}$. The pebble size in the second level is larger; up to $50 \mathrm{~cm}$, but the average size ranges from $(5-35) \mathrm{cm}$ with sub-rounded to sub-angular shapes (Fig. 9 Bottom Left). At the younger level, the average size of the pebbles ranges from (5 15) $\mathrm{cm}$ (Fig. 9 Top Left). This indicates that the river's energy was higher during the older stage of terraces which implies that the depositional period was longer (during Late Pleistocene) and even early Holocene.

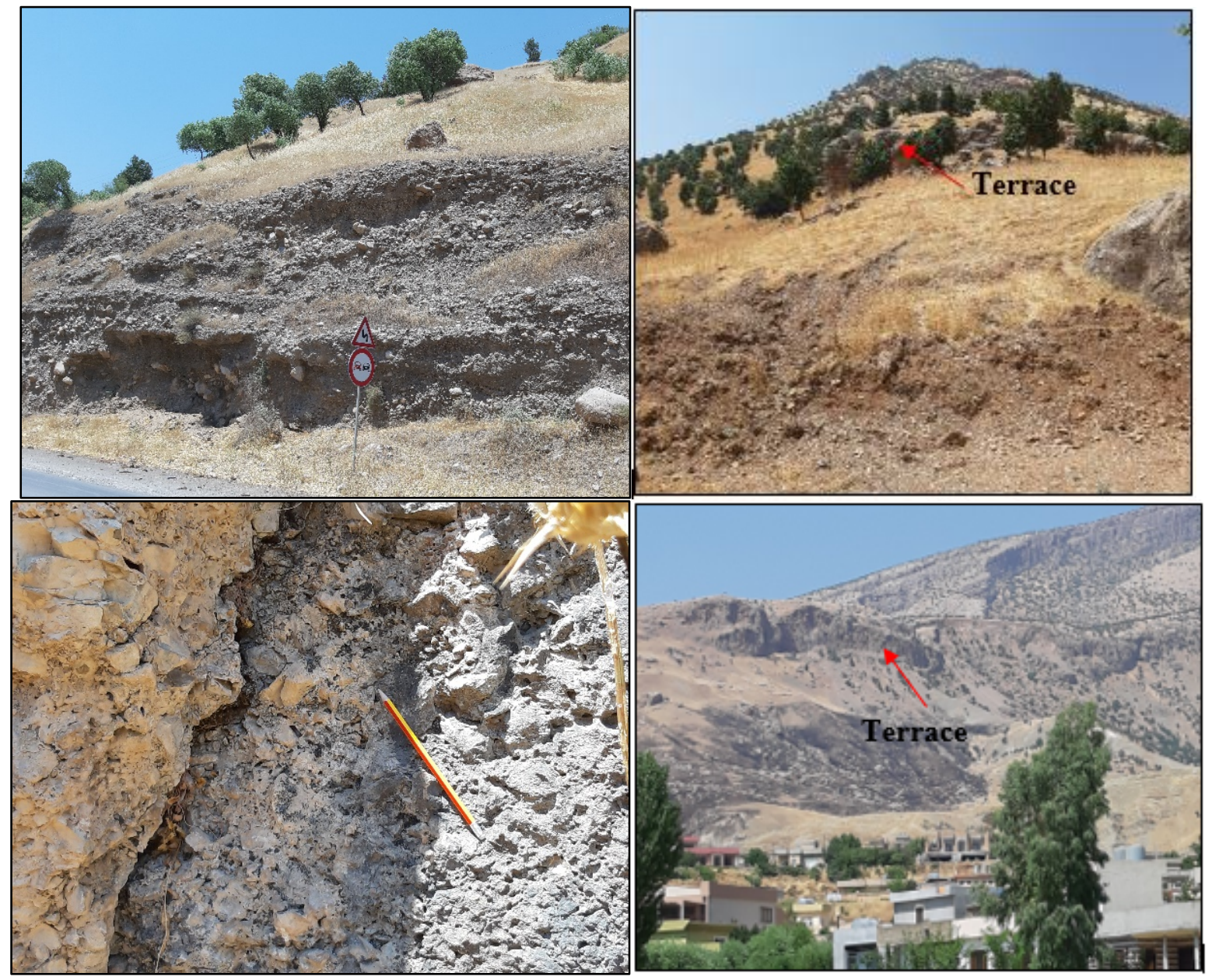

Fig. 9. River terraces of Rawandouz River. Top Left) The third level, Top Right) The second Level, Bottom Left) Pebbles of the second level, Bottom Right) The first level 


\section{DISCUSSION}

The indications for the lateral growth of the studied Handreen, Zozik and Tanoun anticlines are discussed hereinafter.

Water Gaps and Wind Gaps: The presence of water and wind gaps indicates Neotectonic activities and lateral growth of the anticlines as it is presented previously. Zozik and Tanoun anticlines show many examples in different parts; they all are presented in Figs. (6 and 7). It is worth mentioning that Handreen anticline includes three wind gaps which are in high elevations on the top of the anticline and middle of H3 dome (Fig. 8). The absence of water gaps and normal wind gaps in Handreen anticline indicates that the rate of lateral and vertical growth of the anticline is higher than the incision rate of the streams. Whereas, in Zozik and Tanoun anticlines the presence of many water and wind gaps indicate that the rate of stream incision is higher than the rate of lateral and vertical growth of the anticlines. The depth of the water gaps in Zozik anticline is increasing north west wards (Fig. $10 \mathrm{C}$ ) which indicates that the anticline is growing northwest wards (Ramsey et al., 2008). In Tanoun anticline, the depth of the water gaps is almost the same (Fig. $10 \mathrm{D})$. This indicates that the anticline is growing on both sides with the same rate. However, the existence of the thrust fault along the axial plane (Figs. 4 and 8) which has exposed the fairly hard Jurassic rocks may be is the reason for similar erosional and incision rate; since the water gaps are developed within those rocks.

Abandoned Alluvial Fans: The presence of abandoned alluvial fans indicates Neotectonic activities and lateral growth of the anticlines as it is presented previously. Many abandoned alluvial fans are developed along the limbs of Handreen, Zozik and Tanoun anticlines, some of them are presented in Fig. 7. Usually, the alluvial fans are abandoned due to increasing of the lateral growth of the anticlines and/ or decrease in the incision rate of the streams. However, the climatic changes should be not ignored.

En-echelon Plunges and Dome-shaped Anticlines: The studied Handreen, Zozik and Tanoun anticlines exhibit en-echelon plunges and dome shaped folding (Figs. 8 and 10). According to Cowie (1998), aligned fold segments are likely to grow at the expense of other, non-aligned segments, by a positive feedback in the stress changes around the structure. Therefore, fold segments grow in length and divert drainage around their ends. 


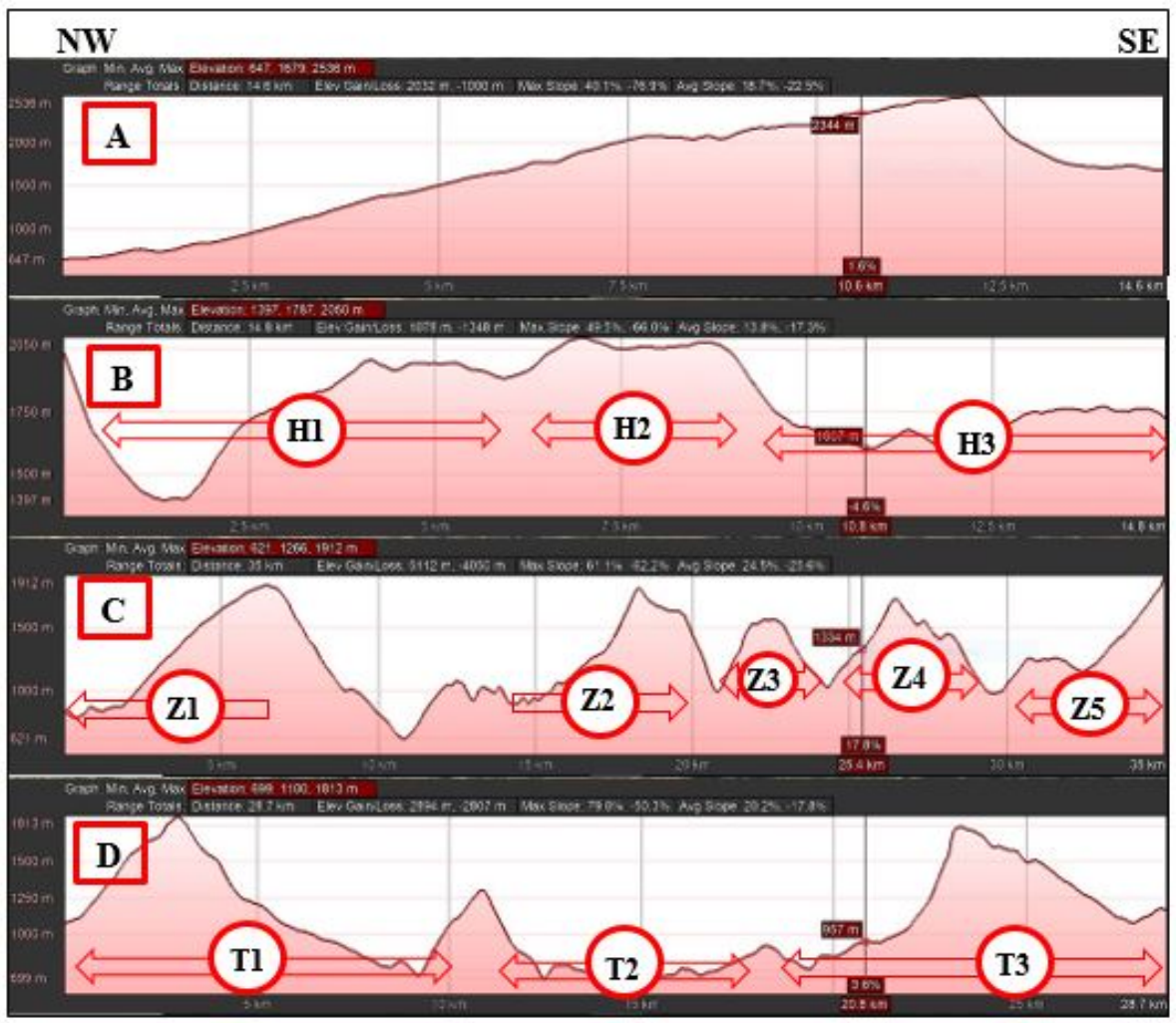

Fig. 10. Four topographic cross sections of the studied anticlines through their axes, (A) Handreen West, (B) Handreen East, (C) Zozik, and (T) Tanoun

A good example is the northwestern plunges of Handreen, Zozik and Tanoun anticlines (Fig. 8), where the streams are shifted, more clearly in Tanoun anticline. Moreover, according to Peacock and Sanderson (1991); Cartwright et al. (1995); Dawers and Anders (1995); Cowie (1998); Blanc et al. (2003); Bennett et al. (2005), and Bull (2007), folds can grow by the lateral propagation of a single segment and merging of several fold segments into one continuous fold. In the studied three anticlines, the dome-shape of Handreen East, Zozik and Tanoun is good indication that the anticlines are growing in a single alignment and the domes will merge with each other forming one single fold. Handreen West anticline is a good example, since there is no any dome within this part. However, the high amplitude of the anticline (Figs. 6, 7, 8 and 10) and the presence of very deeply cut valleys across the anticline can be attributed to the lateral growth and merging of previously existing domes.

River Terraces and Stream Incisions: River terraces and stream incision are good indications for the lateral growth of anticlines (Peacock and Sanderson, 1991; Cartwright et al., 1995; Dawers and Anders, 1995; Cowie, 1998; Keller et al., 1999; Keller and Pinter, 2002; Blanc et al., 2003, Bennett et al., 2005; Bull, 2007; Ramsey et al., 2008). The recognized two terrace levels along 
Rawandouz River and other streams with different thicknesses, heights from the stream level and pebbles' sizes can be explained as follows. The older level is of Lower Pleistocene age which means was deposited during 1.807 Ma; the duration of the Lower Pleistocene (IUGS, 2012). The height difference from the base of the level and the recent river floor is $(75-80) \mathrm{m}$. The younger level which is deposited during Upper Pleistocene which means was deposited during 1143000 years; the duration of the Upper Pleistocene (IUGS, 2012). The height difference from the base of the level and the recent river floor is $(6-8) \mathrm{m}$. Accordingly, the rate of the deposition and rate of the incision of both levels are calculated assuming a constant rate of deposition and incision. The results are presented in Table (2). From the presented data of the deposition and incision rates during the three levels it is clear that the rates are not uniform, and are decreasing from the older stage to the younger. This is attributed to the periodic climatic changes during the Pleistocene and Holocene from wet phase to dry phase.

Table 2. Rate of the deposition and rate of the incision of three terraces levels

\begin{tabular}{|c|c|c|c|c|c|c|}
\hline $\begin{array}{c}\text { Terrace } \\
\text { Level }\end{array}$ & Pleistocene & $\begin{array}{c}\text { Thickness } \\
\mathbf{( m )}\end{array}$ & $\begin{array}{c}\text { Height } \\
\text { from } \\
\text { stream } \\
\text { base (m) }\end{array}$ & $\begin{array}{c}\text { Depositional } \\
\text { duration } \\
\mathbf{( 1 0 0 0} \text { years) }\end{array}$ & $\begin{array}{c}\text { Depositional } \\
\text { Rate } \\
\text { (m/ years) }\end{array}$ & $\begin{array}{c}\text { Incision } \\
\text { Rate } \\
\text { (m/ } \\
\text { years) }\end{array}$ \\
\hline $\begin{array}{c}\text { First } \\
\text { (Older) }\end{array}$ & Lower & $30-35$ & $75-80$ & 1807 & 0.018 & 0.0429 \\
\hline $\begin{array}{c}\text { Second } \\
\text { (Middle) }\end{array}$ & Middle & $3-4$ & $18-20$ & 655 & 0.0053 & 0.029 \\
\hline $\begin{array}{c}\text { Third } \\
\text { (Younger) }\end{array}$ & Upper & $4-6$ & $6-8$ & 1143 & 0.00437 & 0.00612 \\
\hline
\end{tabular}

The first (Oldest) terrace level was recognized in one location only, at the northwestern plunge of Zozik anticline. Most probably, it is mixed with slope sediments derived from the top of Zozik Mountain (Fig. 9, Bottom Right) as it is clear from the presence of large rock blocks mixed with the normal terrace sediments. The size of the pebbles in the terrace levels is also a function of: 1) stream size, 2) gradient of the stream, 3) amount of the running water in the stream, and 4) type of the exposed rocks. In the current stream sediments, different types of rocks and pebbles' sizes can be seen (Fig. 11). These will form the fourth terrace level with different rock types and pebbles' sizes.

Different Types of Valleys: Valleys of different shapes (Fork, cross, inclined (curved), axial, radial) are present in the studied Handreen, Zozik and Tanoun anticlines (Figs. 5, 6, 7 and 11). They are good indications for the lateral growth of the three anticlines, besides other presented and discussed indications. 


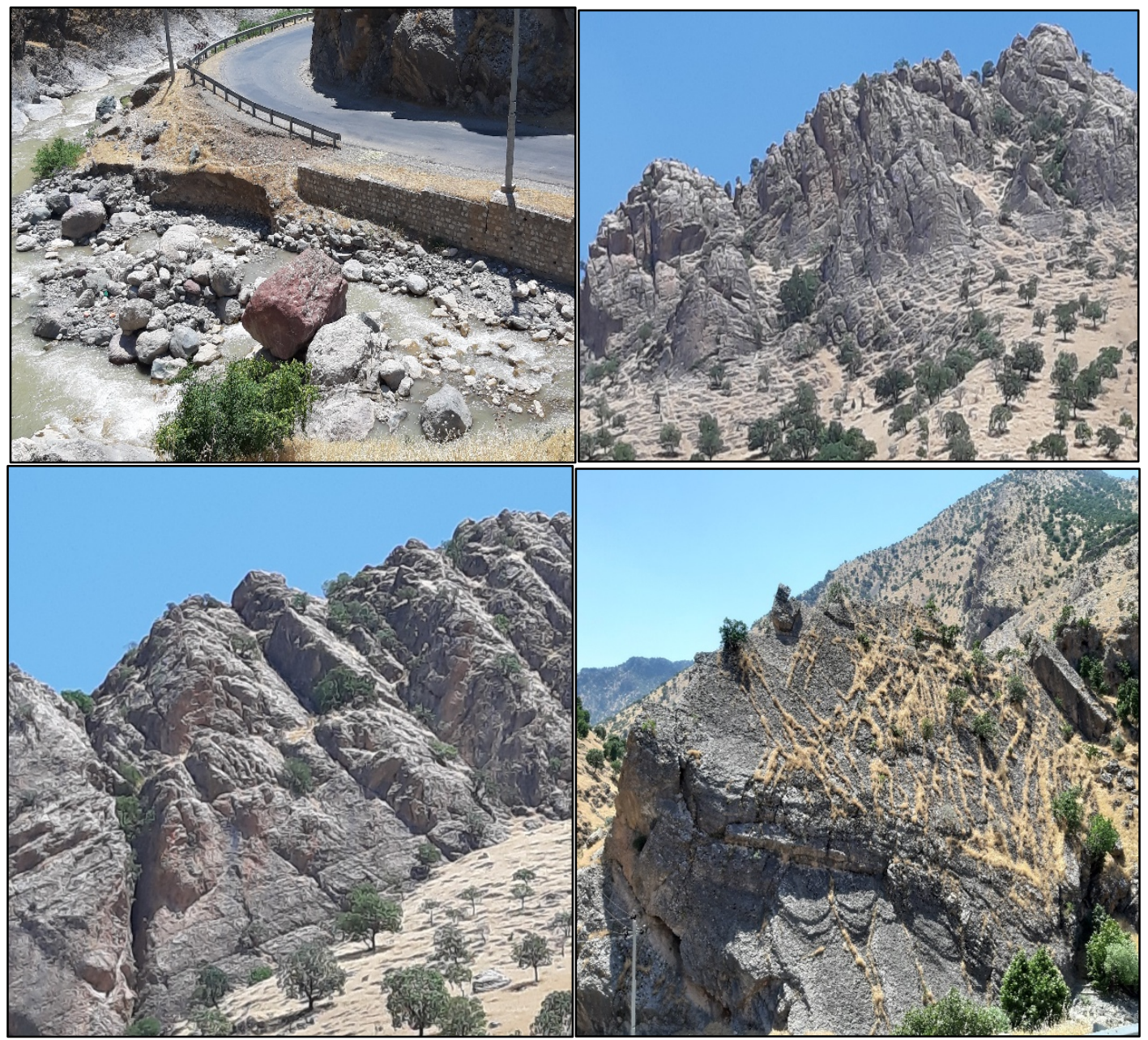

Fig. 11. Top Left) Different rock types and pebbles' sizes in a tributary (water gap in Tanoun anticline, T2 in Fig. 8) of the Rawandouz River, Top Right) Forked-shape valleys, Bottom Left) Inclined valleys, and Bottom Right) Cross-shaped valleys

\section{CONCLUSIONS}

The studied three anticlines, Handreen, Zozik and Tanoun show clear indications for lateral growth. In Handreen anticline, the rate of the lateral growth is higher than that of the stream incision; as indicted by the absence of water gaps and very high topography. In Zozik anticline, the rate of the lateral growth is also higher than the stream incision but not as that of Handreen anticlines. In Tanoun anticline, the rate of the lateral growth is lower than the rate of stream incision as indicated by the presence of three water gaps and absence of wind gap. However, the north western plunge area of Tanoun anticline has higher lateral growth rate than the remaining parts as indicated from the divergent of a stream off the plunge area. The effect of the exposed soft Jurassic rocks in the core of Tanoun anticline (due to the thrust fault) in development of the three water gaps cannot be 
ignored. As the forms of the three anticlines are concerned, Handreen anticline was found to be of two parts (East and West), the eastern part includes three domes. Zozik anticline includes five domes, and Tanoun anticline incudes three domes.

\section{ACKNOWLEDGMENTS}

The current study is a result of a research work carried out at the University of Kurdistan Hewler.

The support of the authorities in the university including the logistics are highly appreciated by the authors. The authors would like to appreciate the efforts of the esteemed reviewers.

\section{REFERENCES}

Alavi, M., 2004. Regional stratigraphy of the Zagros Fold - Thrust Belt of Iran and its proforeland evolution. Amer. Jour. Sci., 304: 1-20.

Al-Kubaisi, M.S. and Abdul Jabbar, M.F., 2015. Effect of lateral propagation of selected folds on streams, Sulaimaniyia Area, NE Iraq. Iraqi Bulletin of Geology and Mining, 11(1): 95 - 124

Allen, M.B., Jones, S., Ismail-Zadeh, A., Simmons, M. and Anderson, L., 2002. Onset of subduction as the cause of rapid Pliocene - Quaternary subsidence in the South Caspian basin. Geology, 30: 775 - 778.

Allen, M., Jackson, J. and Walker, R., 2004. Late Cenozoic reorganisation of the Arabia - Eurasia collision and the comparison of short-term and long-term deformation rates. Tectonics, 23, TC, 2008.

Alvarez, W., 1999, Drainage on evolving fold-thrust belts: a study of transverse canyons in the Apennines: Basin Research, 11:267-284.

Bennett, E., Youngson, J., Jackson, j., Norris, R., Raisbeck, G., Yiou, F. and Fielding, E., 2005. Growth of South Rough Ridge, Central Otago, New Zealand: Using in situ Cosmogenic isotopes and geomorphology to study an active, blind reverse fault. Journal of Geophysics Researches, 110.

Berberian, M., 1993. Tectonic Map of Iran scale 1:1500000. In book: Continental Deformation in the Iranian Plateau, Contribution to the Seismotectonics of Iran, part IV, Publisher: Geological Survey Iran, 52.

Blanc, E.J.P., Allen, M.B., Inger, S. and Hassani, H., 2003. Structural styles in the Zagros simple folded zone, Iran. Journal of Geological Society London., 160: 401 - 412.

Bretis, B., Bartl, N., Grasemann, B., 2011. Lateral fold growth and linkage in the Zagros fold and thrust belt (Kurdistan, NE Iraq). Basin Research 23: 615-630.

Bull, W.B., 2009. Tectonically Active Landscapes. Whilley Blackwell, 326 pp.

Burbank, D.W. and Pinter, N., 1999. Landscape Evolution: The Interactions of Tectonics and Surface Processes. Basin Research, 11:1-6.

Burbank, D.W. and Anderson, R.S., 2001. Tectonic Geomorphology. Blackwell Science Malden, MA, USA.

Cannat, M., Rommevaux-Jestin, C., Sauter, D., Deplus, C. and Mendel, V., 1999. Formation of the axial relief at the very slow spreading Southwest Indian Ridge ( $49^{\circ}$ to $\left.69^{\circ} \mathrm{E}\right)$. Journal of Geophysical Research: Solid Earth, American Geophysical Union, 1999, 104 (B10): 22,825-22,843.

Castelltort, S. and Simpson, G. 2006. River spacing and drainage network growth in widening mountain ranges. Basin Research, 18(3): $267-276$.

Cartwright, J.A., Trudgill, B. and Mansfield, C.S., 1995. Fault growth by segment linkage: an explanation or scatter in maximum displacement and trace length data from the Canyon lands Grabens of SE Utah. Journal of Structural Geology, 17: 1319 - 1326.

Collignon, M., Yamato, P., Castelltort, S., and Boris Kaus, B., 2016. Modelling of wind gap formation and development of sedimentary basins during fold growth: Application to the Zagros Fold Belt, Iran. Earth Surface Processes and Landforms, Wiley, 41(11): 1521 - 1535.

Cowie, P.A., 1998. A healing-reloading feedback control on the growth rate of seismogenic faults. Journal of Structural Geology, 20(8): $1075-1087$. 
Dawers, N.H. and Anders, M.H., 1995. Displacement-length scaling and fault linkage. Journal of Structural Geology, 17: $607-614$.

Décallau, D., Crozza, J.M. and E. Lavile, E., 2006. Recent fold growth and drainage development: The Janauari and Chadigarh anticlines in the Siwalik foothills, Northwest India. Geomorphology, 76: 241-256.

Fouad, S.F., 2012. Tectonic Map of Iraq, scale 1: 1000 000, $3^{\text {rd }}$ edit. Iraq Geological Survey Publications, Baghdad, Iraq.

Ghafur, A.A., Sissakian, V.K., Abdulhaq, H.A. and Omer, H.O., 2019. Aqra Anticline: A Growing Structure at Iraqi Kurdistan Region.

Grasemann, B., and Schmalholz, S., 2012. Lateral Fold Growth and Fold Linage. Geology, 40(11): 1039 - 1042.

Hamza, N.M., 1998. Geomorphological Map of Iraq, scale 1:1000000. Iraq Geological Survey Publications.

IUGS (International Union of Geological Sciences), 2012. Geological Time Scale. Brisbane, Australia.

Keller, E. and Pinter, N., 2002. Active Tectonics, Earthquakes, Uplift and Landscape, $2^{\text {nd }}$ edition. Prentice Hall, 362 pp.

Keller, E. A., Gurrola, L., and Tierney, T. E., 1999. Geomorphic criteria to determine direction of lateral propagation of reverse faulting and folding. Geology, 27(6): $515-518$.

Kennedy, B.A., 1976. Valley-side slopes and climate. In: E. Derbyshire (Ed.) Geomorphology and Climate,171-201, Chichester: Wiley.

Mosavi, E.J., Arian, M., 2015. Tectonic Geomorphology of Atrak River, NE Iran. Open Journal of Geology, 5: 106 -114 .

Mumipour, M., and Najad, H.T., 2011. Tectonic Geomorphology setting of Khayiz anticline derived from GIS processing, Zagros mountain, Iran. Asian Journal of Earth Sciences, 4(3): 1711 - 82.

Oberlander, T.M., 1985. Origin of drainage transverse to structures inorogens. In: Morisawa, M., Hack, J.T. (Eds.), Tectonic Geomorphology. Allen and Unwin, Boston, 155 - 182.

Peacock, D.C.P., and Sanderson, D.J., 1991. Displacements, segment linkage and relay ramps in normal fault zones. Journal of Structural Geology, 13: $721-733$.

Ramsey, L.A, Walker, R,T. and Jackson, J., 2008. Fold Evolution and Drainage Development in the Zagros Mountains of Fars Province, SE Iran. Basin Research, 20: 23 - 48.

Sissakian, V.K., 2010. Neotectonic movements in Darbandi Bazian Area, southwest of Sulaimaniyah city, NE Iraq. Iraqi Bulletin of Geology and Mining, 6(2): $57-69$.

Sissakian, V.K. and Abdul-Jabbar, M.F., 2010. Morphometry and genesis of the main Transversal Gorges in North and Northeast Iraq. Iraqi Bulletin of Geology and Mining, 6(1): $95-120$.

Sissakian, V.K. and Fouad, S.F., 2012. Geological Map of Iraq, scale 1: 1000 000, 4th edition. Iraq Geological Survey Publications, Baghdad, Iraq.

Sissakian, V.K. and Fouad, S.F., 2014. Geological Map of Erbil and Mahabad Quadrangles, scale 1: 250000, $2^{\text {nd }}$ edition. Iraq Geological Survey Publications, Baghdad, Iraq.

Sissakian, V.K., Kadhum, T.H., and Abdul Jab'bar, M.F., 2014. Geomorphology. In: The Geology of the High Folded Zone. Iraqi Bulletin of Geology and Mining, 6: 7 - 56.

Sissakian, V.K. and Al-Jiburi, B.M., 2014. Stratigraphy. In: Geology of the High Folded Zone. Iraqi Bulletin of Geology and Mining, 6: $73-161$.

Sissakian, V.K., Ameen, R.M. and Mohammed, J. Gh., 2018. Lateral Growth of Qara Dagh Anticline, South of Sulaimaniyah City, NE Iraq: A Structural - Geomorphological Study. Iraqi Bulletin of Geology and Mining, 14(2): $9531-47$.

Skilodimou, H.D., Bathrellos, G.D., Maroukian, H. and Gaki-Papanastassiou, H.K., 2014. Late Quaternary evolution of the lower reaches of Ziliana stream in south Mt. Olympus (Greece). Geografia Fisica e Dinamica Quaternaria, 37(1): $43-50$.

Tomkin, J.H. and Braun, J., 1999. Simple models of drainage reorganisation on a tectonically active ridge system. New Zealand Journal of Geology and Geophysics, 42(1): 1 - 10.

Whitney, B.B., and Hengesh, J.V., 2015. Geomorphological evidences of Neotectonic deformation in the Carnacaran Basin, Western Australia. Geomorphology, 228: 579 - 596. 